Forms of Knowledge in Early Modern Asia 



\section{Forms of Knowledge in Early Modern Asia}

Explorations in the Intellectual History

of India and Tibet, 1500-1800

Edited by

Sheldon Pollock

Duke University Press · Durham and London · 2011 
(C) 2011 Duke University Press

All rights reserved

Printed in the United States of America

on acid-free paper $\otimes$

Typeset in Arno by Tseng Information Systems, Inc.

Library of Congress Cataloging-in-Publication Data appear on the last printed page of this book. 
In memory of

our dear friend

and colleague,

Aditya Behl

(1966-2009) 
